Hydrol. Earth Syst. Sci. Discuss., https://doi.org/10.5194/hess-2017-357

Manuscript under review for journal Hydrol. Earth Syst. Sci.

Discussion started: 11 July 2017

\title{
Combined impact of local climate and soil properties on soil moisture patterns
}

\author{
Thushara Gunda ${ }^{1}$, Udeni P. Nawagamuwa ${ }^{2}$, and George M. Hornberger ${ }^{1}$ \\ ${ }^{1}$ Vanderbilt University Institute for Energy and the Environment, Department of Civil and Environmental Engineering, \\ Vanderbilt University, Nashville, TN, USA \\ ${ }^{2}$ Department of Civil Engineering, University of Moratuwa, Katubedda, Moratuwa, Sri Lanka (10400) \\ Correspondence to: Thushara Gunda (tgunda@gmail.com)
}

\begin{abstract}
Soil plays a key role in terrestrial water dynamics by retaining precipitation on land. A water balance approach is used to evaluate spatial and temporal variations in soil moisture in Sri Lanka, a country characterized by high spatial variability as reflected in the recognition of three regions of the country, the wet zone, the intermediate zone, and the dry zone. We show that a combination of local climate and soil properties drive spatial patterns of soil moisture deficits on the island, with soils buffering climate variability in the wet zone and enhancing drought patterns in the dry zone. Changes in historical temporal patterns are most notable for the intermediate zone, a region characterized by consistently variable deficits. Counterfactuals of climate change scenarios indicate temperature will drive increases in deficit likelihoods (up to $20 \%$ ) in the future, with greatest impact in the intermediate and dry zones, where more than $80 \%$ of the national rice production is concentrated. Given that temperature projections are less uncertain than other climate change impacts, further evaluation of future water stresses are needed. Coupled with remotely-sensed soil moisture data, the findings from this study have implications for infrastructural planning and seasonal crop water allocations in zones with a degree of variability (i.e., neither consistently wet nor consistently dry). Because soil hydrologic regimes reflect inherent, local vulnerabilities, water management decisions need to incorporate regional variabilities in soil moisture dynamics in assessments of climate change adaptations.
\end{abstract}

Copyright statement. The authors certify that they have read and agree to the terms outlined by HESS.

\section{Introduction}

Soil moisture plays a key role in hydrological processes (such as runoff generation) and ecosystem functions (such as soil respiration and soil carbon and nutrient cycling) (Botter et al., 2007; Manzoni et al., 2012). In addition to influencing soil forming processes (Karmakar et al., 2016), soil moisture serves as a critical storage reserve of water for evapotranspiration processes (McColl et al., 2017). Strong relationships observed with crop yields underscore the importance of monitoring soil moisture for food security (Holzman et al., 2014). Characterizing soil moisture variability has provided valuable insights into droughts, extreme temperatures, floods, and thunderstorms (Fournier et al., 2016; Heim Jr, 2002; Koster et al., 2004; Massari et al., 2014; McColl et al., 2017; Whan et al., 2015). 
Hydrol. Earth Syst. Sci. Discuss., https://doi.org/10.5194/hess-2017-357

Manuscript under review for journal Hydrol. Earth Syst. Sci.

Discussion started: 11 July 2017

(c) Author(s) 2017. CC BY 4.0 License.

Soil moisture is influenced by both physical and social variables. Temperature directly impacts the loss of water from soil through evapotranspiration while precipitation serves as a source of water (Várallyay et al., 2010). Soil moisture is also influenced by land use patterns, which can drive differences in evapotranspiration and physical properties of soil (Fu et al., 2003). In particular, land management and irrigation practices in agricultural areas can greatly influence soil moisture dynamics (Pender and Kerr, 1998); irrigation practices may vary depending on farmers' sensitivities to changes in soil water content (Du et al., 2017).

Assessing the potential impacts of climate change on soil moisture regimes is complex because of the strong feedbacks to both temperature and precipitation changes (Seneviratne et al., 2010; Várallyay et al., 2010). Future projections of temperature changes generally have lower uncertainties than those for precipitation (IPCC, 2014). Mean surface temperatures are expected to increase between 1.1 and $4.8 \mathrm{C}$, with greater impacts at higher latitudes; precipitation changes are much more variable both geographically and seasonally, making quantitative estimates more uncertain (IPCC, 2014). Societal impacts of climate change are expected to vary globally, with agricultural production in regions at lower latitudes disproportionally impacted due to low adaptive capacity and already high temperatures (Gunda et al., 2017). Given that crop productivity is strongly impacted by water availability (Kang et al., 2009), understanding potential impacts of climate change on soil moisture is particularly important for development of informed adaptation strategies.

Although studies have quantified impacts of climate change on soil moisture at both global (e.g., Berg et al. (2017)) and regional (e.g., Eitzinger et al. (2003)) scales, limited attention has been given to characterizing differences in soil moisture patterns arising from variabilities in local climate and soil conditions. Research shows that evapotranspiration at the scale of a watershed is related to climate drivers and to soil capacity to retain water in complex ways (Garcia and Tague, 2015) and that long-term patterns in soil moisture reflect climate interactions with soil water retention capacity (Salley et al., 2016). Because soil properties are intrinsic characteristics of local systems, societal responses may need to account for regional variabilities in soil moisture patterns in planning efforts.

In our work, we explore how climate and soil interact using both historical climate observations and stylized climate change scenarios. Specifically, we aim to assess how spatial variations in climate and soil properties influenced patterns of soil moisture over the last century and how spatial and seasonal variations of soil moisture may change in the future due to climate change. We use a water balance approach in conjunction with counterfactuals to address the research questions; satellite data is used to evaluate the general patterns identified by the water balance approach. The island nation of Sri Lanka is largely agricultural with high spatial and temporal rainfall variability (Gunda et al., 2016). We use this area for analysis as it has the high spatial variability characteristics that underlie our questions. Our results suggest that spatial differences in soil moisture variability are driven by a combination of climate and soils, with the latter buffering the magnitude and timing of deficits during wet conditions. Both historical patterns and climate change impacts exhibit spatial variability, with deficits in the zones with a degree of variability (i.e., neither consistently wet nor consistently dry) most likely to be amplified in the future. 
Hydrol. Earth Syst. Sci. Discuss., https://doi.org/10.5194/hess-2017-357

\section{Methods}

\subsection{Study site}

Located off the southeast coast of India, the island of Sri Lanka experiences a tropical climate. The physiography of Sri Lanka consists of a sloping topography with high country (i.e., elevation $>1000 \mathrm{~m}$ ) in the center of the island that drops to less

5 than $100 \mathrm{~m}$ along the coast (Figure 1). The average temperature on the island is $27 \mathrm{C}$ except in the central highlands, where temperatures are $15 \mathrm{C}$. Annual precipitation ranges between 1000 and $3600 \mathrm{~mm}$ on the island, with the wet zone receiving more than $2500 \mathrm{~mm}$ of rainfall and the dry zone receiving less than $1750 \mathrm{~mm}$ (Zubair, 2003). The rainfall differences arise from the southwest portion of the island receiving rainfall during both the southwest monsoon (May-Sept) and the northeast monsoon (Dec-Feb) while the dry zone only receives rainfall during the latter; the intermediate zone is a transition region (Gunda et al., 2016). In addition to rainfall, the three zones are also demarcated by varying soil types, with latosols and regosols (LRs) being most prevalent in the wet zone, reddish brown earths (RBEs) and red latosols (RLs) in the dry zone, and a mixture of soils in the intermediate zone; RLs underlie the northwest coastal regions of the island of Puttalam and Jaffna. LRs are characterized by high water holding capacities while RBEs and RLs have low water holding capacities (Moorman and Panabokke, 1961; Cooray, 1984). RBEs and RLs are also characterized by rapid infiltration and rapid releases of soil moisture at low tensions (DOA, 2017). Rice production (the staple food of the country) occurs predominantly in the intermediate and dry zone districts of the country (Davis et al., 2016). The limited water supplies during the period from April to August are supplemented by local reservoirs in the intermediate zone and by the Mahaweli irrigation system, which diverts water from the central highlands to the lowlands, in the dry zone. Sri Lanka has been self-sufficient in rice production since 2005 but elevated temperatures and shifting precipitation patterns are sources of crop stress for the future (Davis et al., 2016).

\subsubsection{Soil moisture calculations}

Strong correlation between Palmer Drought Severity Index (PDSI)-derived soil moisture and independent soil moisture estimates have been observed globally (Dai et al., 2004; Szép et al., 2005). A common measure of agricultural drought, PDSI uses a physical water balance in a 2-layered, 1-m soil system (Palmer, 1965). Precipitation and recharge are inputs into the soil system while evapotranspiration and runoff are outputs. Runoff is dependent on the saturation of the underlying soils, which are characterized by the available water content (AWC) and antecedent conditions. The time scale of PDSI is approximately 9 months (Heim Jr, 2002). A calculation of soil moisture content as part of the balance allows use of PDSI as a soil moisture indicator (Dai et al., 2004; Szép et al., 2005). The primary advantage of using a drought index approach is that it can leverage long temporal records of meteorological data (Seneviratne et al., 2010).

Monthly soil moisture was calculated at 13 stations in Sri Lanka (Figure 1), using the PDSI tool provided by Jacobi et al. (2013) with the Thornthwaite method for calculating potential evapotranspiration values and the full period of record for calibration. Long-term, monthly precipitation and average temperature data for the 13 stations, were obtained from the Meteorological Department of Sri Lanka and processed as outlined in Gunda et al. (2016); the 13 stations capture the climate spatial variabilities of the country (Gunda et al., 2016). PDSI was calculated on data from 1875 to 2016, with stable values achieved 
Hydrol. Earth Syst. Sci. Discuss., https://doi.org/10.5194/hess-2017-357

Manuscript under review for journal Hydrol. Earth Syst. Sci.

Discussion started: 11 July 2017

(c) Author(s) 2017. CC BY 4.0 License.
Hydrology and

Earth System

Sciences

Discussions

(c) (i)

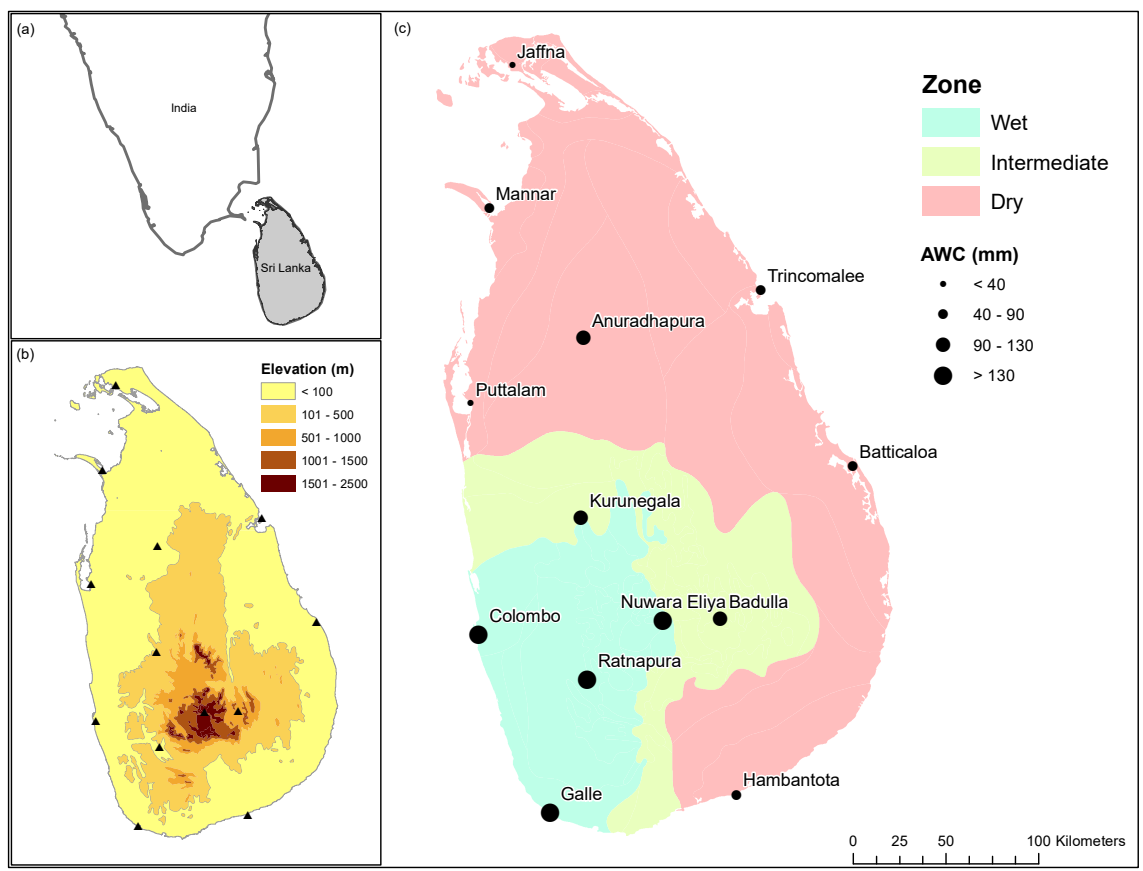

Figure 1. Stations with long-term historical data in Sri Lanka. (a) General location of Sri Lanka, (b) local topography with station locations, and (c) zone boundaries with station locations, with marker size indicating the local available water content (AWC) of soils. Water is captured in the high elevation regions of the country and transferred to the lowlands to the north and southeast for agricultural production.

from Jan 1878 to Mar 2014. AWC values were derived from the literature and range from $37 \mathrm{~mm}$ in the northwest coastal regions to $187 \mathrm{~mm}$ in the wet zone (Aydin et al., 2012; De Silva and Rushton, 2007; Mikunthan and De Silva, 2010; Keerthisena et al., 2001; Mapa et al., 2010; Rajapaksha et al., 2002) (Figure 1). Soil moisture deficits (SMD), a common metric for climate change analysis (Cohen et al., 1996), were estimated by subtracting soil moisture values from the corresponding AWC values.

5 The SMDs were normalized by AWCs to represent the fraction of soil moisture deficit relative to the local available water content for the top $1 \mathrm{~m}$ (Peng et al., 2017).

SMD estimates at the 13 stations were evaluated as a function of zone, AWC, and season to understand spatial and temporal patterns of variability. Median and standard deviation SMD values were calculated for each month to explore both the magnitude and timing of deficits. Seasonal patterns were also evaluated using soil moisture data observed directly by the Soil Moisture Active Passive (SMAP) mission, which was launched in January 2015. SMAP measures volumetric soil moisture in the top $5 \mathrm{~cm}$ of the soil (Sun et al., 2017). A Level 3, 36-km gridded product (L3_SM_P) derived from the passive sensor was used to develop monthly estimates of soil moisture. Grid values were extracted for the 13 station locations; cells with high percentage of water bodies and excessive vegetation were excluded from analysis. Temporal patterns were characterized by calculating exceedance probabilities of mean annual deficits, both for the full record and for the record split into two periods 
Hydrol. Earth Syst. Sci. Discuss., https://doi.org/10.5194/hess-2017-357

Manuscript under review for journal Hydrol. Earth Syst. Sci.

Discussion started: 11 July 2017

(c) Author(s) 2017. CC BY 4.0 License.

("Until 1946" and "After 1946") to evaluate changes in the historical record. The nonparametric Wilcoxon-Mann-Whitney test was used to assess differences in the two period probability curves (Conover and Iman, 1981).

\subsubsection{Climate scenario analysis}

Both elevated temperatures and shifting precipitation patterns can impact SMDs. Climate change projections for Sri Lanka note

5 consistent increases in temperature throughout the year while precipitation shifts are variable based on the season (De Silva et al., 2007; Zubair et al., 2015). The largest modes of precipitation variability coincide with periods of high rainfall, notably during Apr-Jun and Oct-Dec (Zubair et al., 2015). Some model projections show increases in rainfall while others show decreases for the future (Seo et al., 2005). The large range of projections is driven by complex monsoon dynamics in the Indian Ocean that lead to large biases in the climate models (Li et al., 2015).

To assess sensitivity of SMDs to elevated temperatures, we consider warming scenarios of $1 \mathrm{C}, 2 \mathrm{C}$, and $3 \mathrm{C}$ to account for the range of conditions projected for Sri Lanka (Zubair et al., 2015). For each warming scenario, we consider the "worst case scenario" of an added impact of a $10 \%$ decrease in precipitation during the high rainfall months of Apr-Jun and Oct-Dec aforementioned. Because antecedent conditions are incorporated in the PDSI calculations, the sequence of meteorological occurrences are important. Therefore, the sensitivity of SMDs to elevated temperatures and reduced precipitation were evaluated using a counterfactual approach, whereby we impose the climate change patterns on the historical data set. In other words, the historical meteorological data at each station was modified by climate change patterns (i.e., warming only or warming and seasonal precipitation decreases) and then inputted into the PDSI tool to estimate SMDs and evaluate how soil moisture deficit patterns could change in the future. This approach would limit overestimation issues since climate change projections imposed on the record are dynamically accounted for in the PDSI calculations, rather than being imposed on mean patterns (Berg et al., 20 2017).

\section{Results}

Deficits are generally lowest in the wet zone and highest in the dry zone, with the intermediate zone experiencing consistently high variability in monthly values (Figure 2). There is little intra-zone variability in the intermediate and dry zones; the wet zone stations of Nuwara Eliya and Ratnapura have much lower deficits and associated variabilities than those observed at the other two wet zone stations (Figure A1). Jan-Mar deficits in the wet zone are driven by the coastal stations, Colombo and Galle, which have high standard deviations throughout the year (Figures 3 and A2). High deficits (i.e., fraction of AWC $>0.7$ ) are present Jul-Sep in the intermediate zone and Feb-Sep in the dry zone, with high variability Oct-Jan and low variability May-Aug in the dry zone (Figures 3 and A2).

SMAP data show higher soil moisture in Colombo and low soil moisture Jan-Mar and Jul-Sep at all three stations (Figure 4). During the first six months of the year, satellite data indicate peak surface soil moisture in May at Kurunegala and Anuradhapura while water balance data indicate lowest deficits in April in the top $1 \mathrm{~m}$ of soil at those locations (Figure 4). Exceedance probability curves of the three zones highlight the prevalence of deficits in the dry zone, with the intermediate zone observing 
Hydrol. Earth Syst. Sci. Discuss., https://doi.org/10.5194/hess-2017-357

Manuscript under review for journal Hydrol. Earth Syst. Sci.

Discussion started: 11 July 2017

(c) Author(s) 2017. CC BY 4.0 License.

(c) (i)
Hydrology and

Earth System

Sciences

Discussions
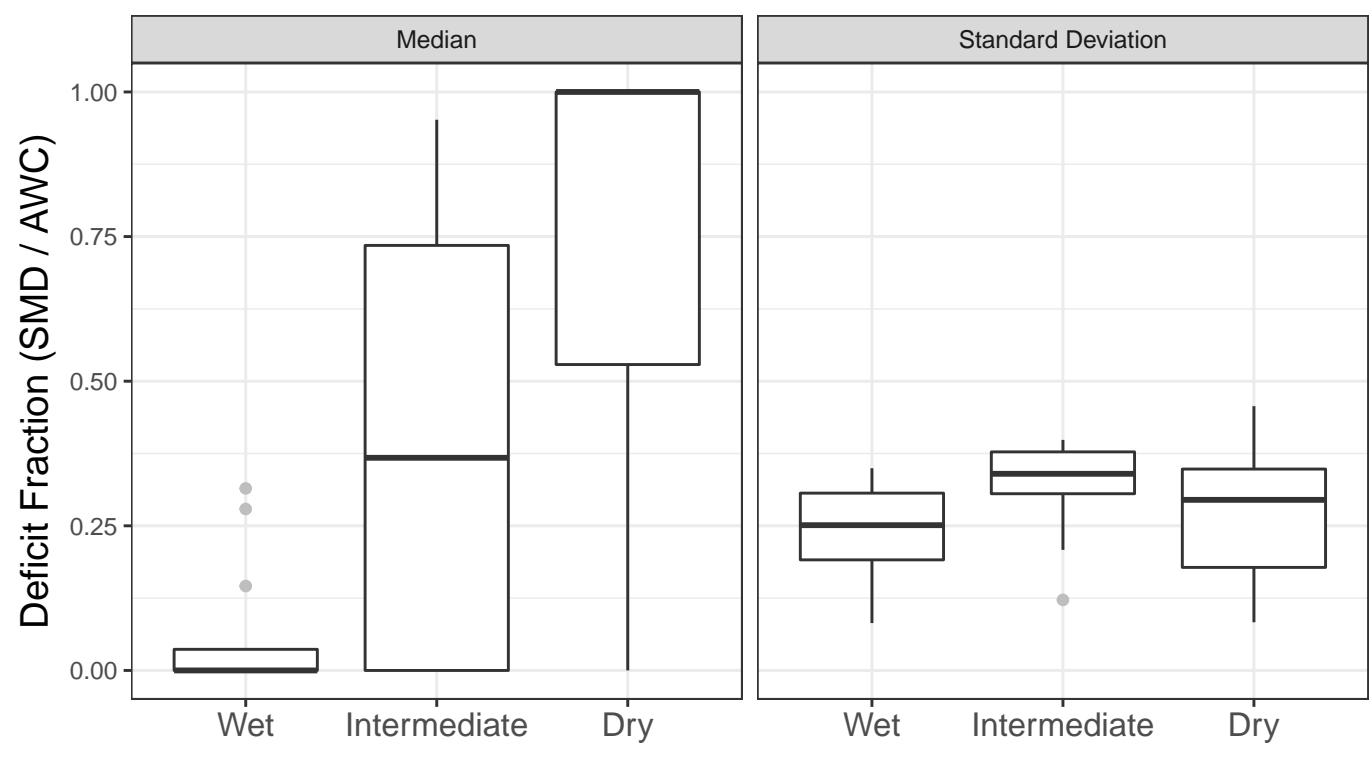

Figure 2. Distribution of median (left) and standard deviation (right) of monthly deficits. The rectangle of each boxplot shows the first to third quartile of the data (with the median represented by the segment); the lines indicate minimum and maximum values. Monthly values in the intermediate zone span a consistently larger range of deficits than those observed in the wet or dry zones.

the largest range of mean annual deficit values (Figure 5). Exceedance probabilities significantly decrease for a given mean annual deficit after 1946 in both the intermediate (consistently up to $15 \%$ ) and dry zone (up to $25 \%$ at high deficits) (Figure 5). At the station-level, significant differences were observed at Anuradhapura and Colombo, with the latter exhibiting less severe deficits after 1946 (Figure A3).

Under climate change scenarios, deficits generally increase with temperature, with significant differences observed between the historical values and all of the scenarios except for the 1C warming only scenario across all three zones (Figure 6). Probability shifts are observed between historical values and warming conditions in the intermediate zone at 2C and 3C (12-21 $\%)$ and in the dry zone (16-22\%). For a scenario of a $2 \mathrm{C}$ warming coupled with a $10 \%$ decrease in precipitation, there is an additional shift of $7 \%$ in the intermediate zone and $11 \%$ in the dry zone (Figure 6). Significant differences between elevated temperature curves and additional reduced precipitation curves are observed only in the dry zone for all three temperature conditions (Figure 6). Median deficits increase Jan-Mar in the wet zone across all three temperature conditions (Figure 7). In the intermediate zone, median deficits increase Jan-Mar and May-Sep across the warming conditions, with increases also occurring in Apr under the reduced precipitation scenarios (Figure 7). In the dry zone, median deficits primarily increase in Oct and in Jan across the three temperature conditions. Generally, the standard deviations increase with increases in the median except where deficit medians approach the AWCs (Figure 7). At the station-level, significant differences between scenarios are observed in two of the wet zone stations, both of the intermediate zone stations, and one of the dry zone stations (Table A1). 
Hydrol. Earth Syst. Sci. Discuss., https://doi.org/10.5194/hess-2017-357

Manuscript under review for journal Hydrol. Earth Syst. Sci.

Discussion started: 11 July 2017

(c) Author(s) 2017. CC BY 4.0 License.
Hydrology and

Earth System

Sciences

Discussions

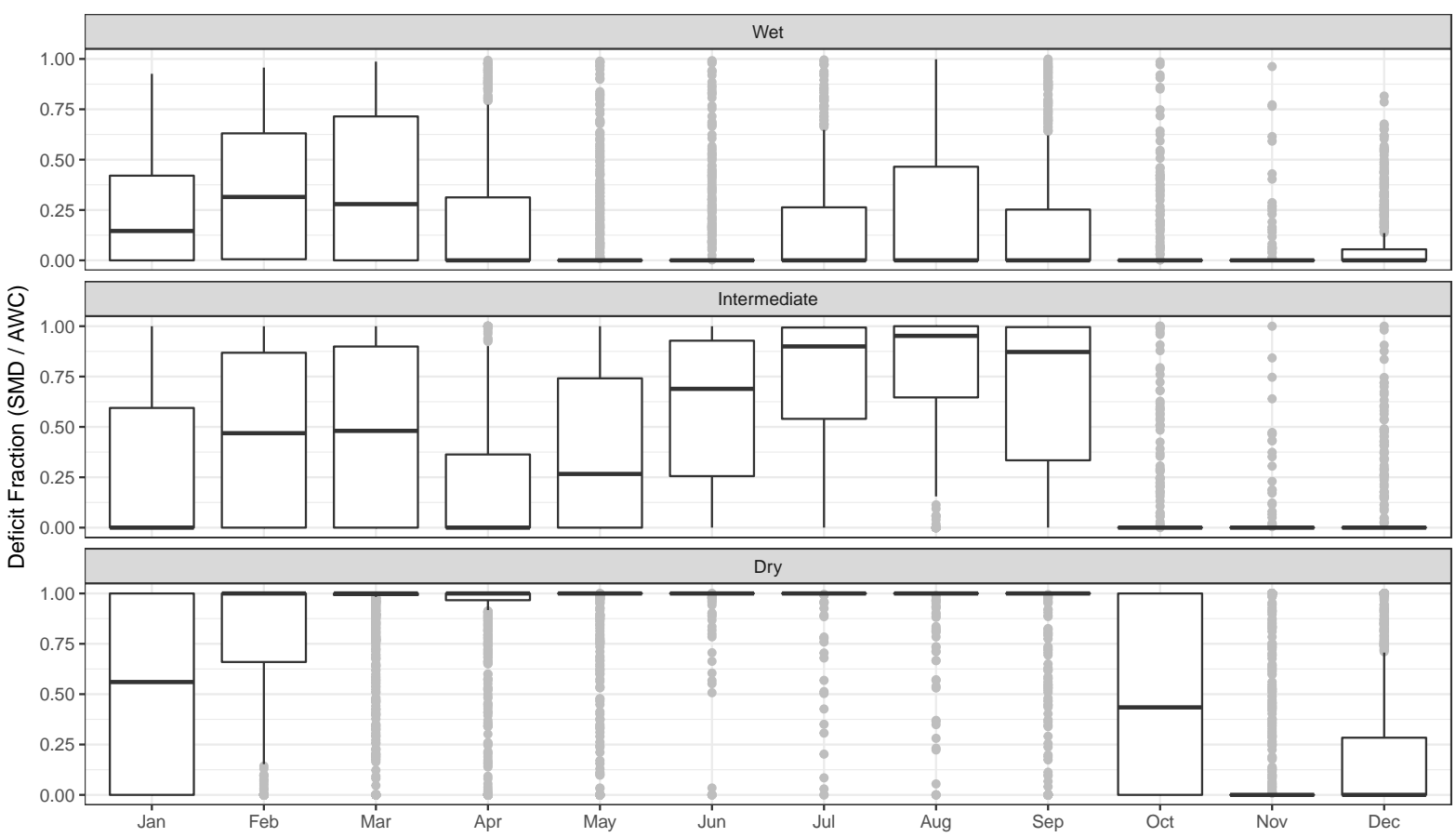

Figure 3. Monthly soil moisture deficit fractions in the three zones. High deficits are prevalent Jul-Sep in the intermediate zone and Feb-Sep in the dry zone.

\section{Discussion}

Spatial and temporal patterns of soil moisture deficit are conditioned both by the ability of soils to retain water and by climate conditions. In Sri Lanka, deficits showed consistent patterns within the three zones (Figure 2). Of the four wet zone stations, the two in the central mountains show similar temporal patterns with essentially no deficits and little variability (Figure A1).

5 Soil moisture deficits for the two wet zone stations on the coast, on the other hand, are noticable in some months (February and March in particular) and are much more variable throughout the year (Figure A2) reflecting the importance of intra-zonal variations arising from local climate conditions. The soils in the wet zone have high water holding capacities (potentially indicative of historical climate controls (Hawkes et al., 2017)) that effectively buffer the impacts of climate variability on SMDs resulting in overall low annual deficits in the region (Figure 5). In contrast to the wet zone, consistently high SMDs are present in the dry zone, indicating that the combination of low water holding capacities of soil and drier climates leads to high drought prevalence in this region (Folberth et al., 2016). Drought conditions are present Feb-Sep in the dry zone. The intermediate zone is characterized by consistently variable deficits (Figure 2), resulting in the largest range of deficit values observed in the historical record (Figure 5). The low deficits that occur commonly in the central highlands (Figure A2) provide part of the explanation for high landslide hazards in the region (e.g., (Zubair et al., 2005)). 
Hydrol. Earth Syst. Sci. Discuss., https://doi.org/10.5194/hess-2017-357

Manuscript under review for journal Hydrol. Earth Syst. Sci.

Discussion started: 11 July 2017

(c) Author(s) 2017. CC BY 4.0 License.
Hydrology and

Earth System

Sciences

Discussions

(c) (i)
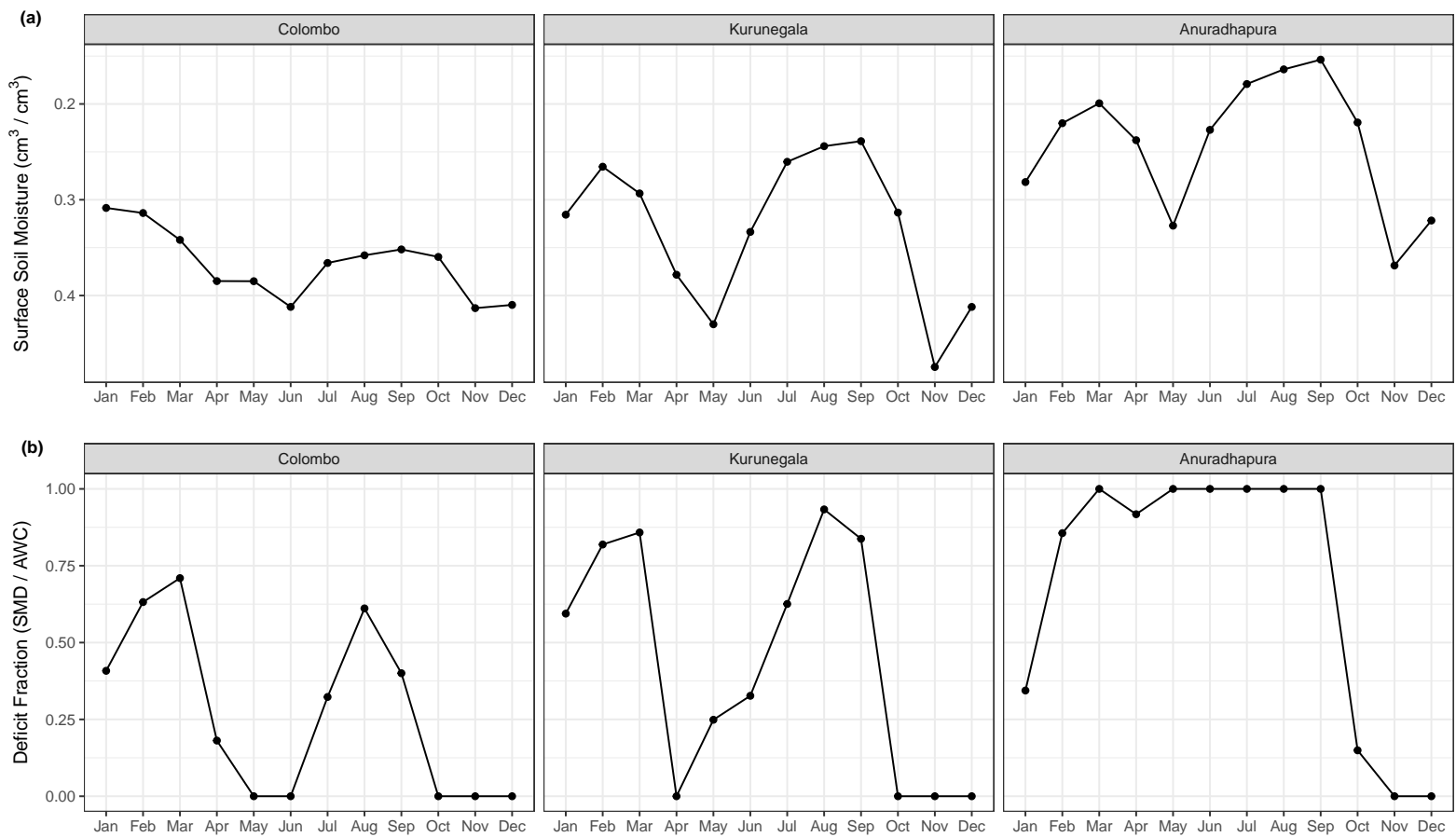

Figure 4. Seasonal patterns of (a) surface (top $5 \mathrm{~cm}$ ) soil moisture from SMAP data and (b) soil moisture deficits from water balance for top $1 \mathrm{~m}$ at three representative stations. Note the inverted vertical axis for (a). Colombo (wet zone) generally has higher soil moisture than Kurunegala (intermediate zone) and Anuradhapura (dry zone).

Seasonal patterns of surface soil moisture data from SMAP are similar to those observed from the calculated deficits (Figure 4), a finding consistent with the general agreement typically observed between moisture dynamics at the surface and the total unsaturated soil zone (Berg et al., 2017). For example, the periods of high deficits at Kurunegala coincide with months of low soil moisture observed by SMAP. We attribute the difference in peak soil moisture at Anuradhapura and Kurunegala (May per SMAP but April per water balance method) to the release of irrigation water for rice planting (MASL, 2015) that is not accounted for in the SMD calculations. A significant advantage of SMAP-derived data is the availability of soil moisture near real-time, every 2-3 days. However, the current spatial resolution of $36 \mathrm{~km}$ and poor signal quality in heavily forested regions and along coastal regions are notable limitations of this dataset. Continued development of statistical downscaling methods indicate promise for applying SMAP data to a scale usable for water management practices (Peng et al., 2017), especially, in conjunction with seasonal forecasting of vegetation health (Bolten and Crow, 2012) and early warning systems of drought (McColl et al., 2017).

Analyses indicate that the climate has changed in Sri Lanka over the past century (e.g., De Silva and Sonnadara (2016)). The shifts in exceedance probabilities for SMDs pre- and post- 1946 indicate a general increase in likelihood across all deficits in the intermediate zone and at high deficits in the dry zone in the latter half of the century (Figure 5). Comparison of the 
Hydrol. Earth Syst. Sci. Discuss., https://doi.org/10.5194/hess-2017-357

Manuscript under review for journal Hydrol. Earth Syst. Sci.

Discussion started: 11 July 2017

(c) Author(s) 2017. CC BY 4.0 License.

(c) (i)
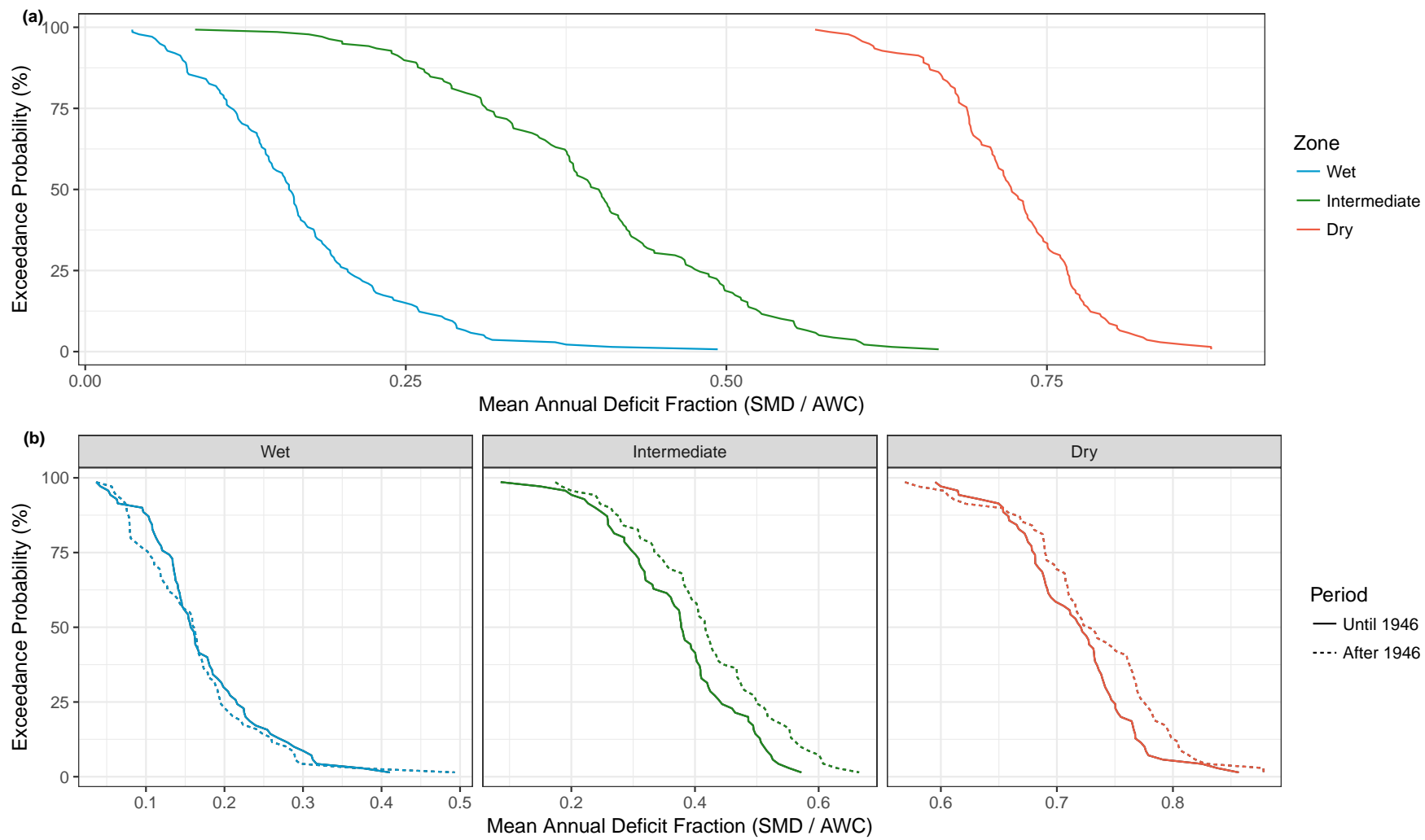

Period

- Until 1946

-... After 1946

Figure 5. Exceedance probability curves of mean annual deficit of soil moisture for (a) the entire period of record and (b) comparison of two period halves. (a) There is a $50 \%$ chance that deficits exceed 0.16 (wet zone), 0.40 (intermediate zone), and 0.72 (dry zone). (b) Exceedance probabilities for a given deficit are greater after 1946 in the intermediate zone $(\mathrm{p}<0.05)$ and the dry zone $(\mathrm{p}<0.1)$.

annual cumulative distributions of SMD for "Until 1946" with the distributions for "After 1946" indicates significant change for only a few stations (Figure A3). At Anuradhapura, a total annual SMD of 825mm was $25 \%$ more likely to occur in the latter period than in the earlier period (Figure A3). Although the rainfall at Nuwara Eliya has declined by about $25 \%$ (De Silva and Sonnadara, 2016), there is enough water to keep the SMD at a minimal level. The hydrological impact is not on the local SMD but rather on the surplus of water available to run off. Given that transfer of water from the central highlands (e.g., Nuwara Eliya district) to the lowlands (e.g., Anuradhapura district) for irrigation is important for rice production, the lack of significant change of SMD historically in the wet zone cannot be interpreted as being of little consequence.

Temperature changes (which generally have the lowest associated uncertainty of climate change projections) drive significant increases in soil moisture deficits across the country (Figure 6). The impacts of $2 \mathrm{C}$ and $3 \mathrm{C}$ temperature increases at intermediate and dry zones (probability shifts of up to $20 \%$ ) impose a considerable threat to soil moisture. Although reduced precipitation is projected for Sri Lanka (Shantha and Jayasundara, 2005; De Silva et al., 2007), marginal impacts of precipitation on deficit probabilities are lower than those for temperature increases alone. At the station-level, significant shifts from both warming 
Hydrol. Earth Syst. Sci. Discuss., https://doi.org/10.5194/hess-2017-357

Manuscript under review for journal Hydrol. Earth Syst. Sci.

Discussion started: 11 July 2017

(c) Author(s) 2017. CC BY 4.0 License.

\section{(c) (1)}

Hydrology and

Earth System

Sciences

Discussions
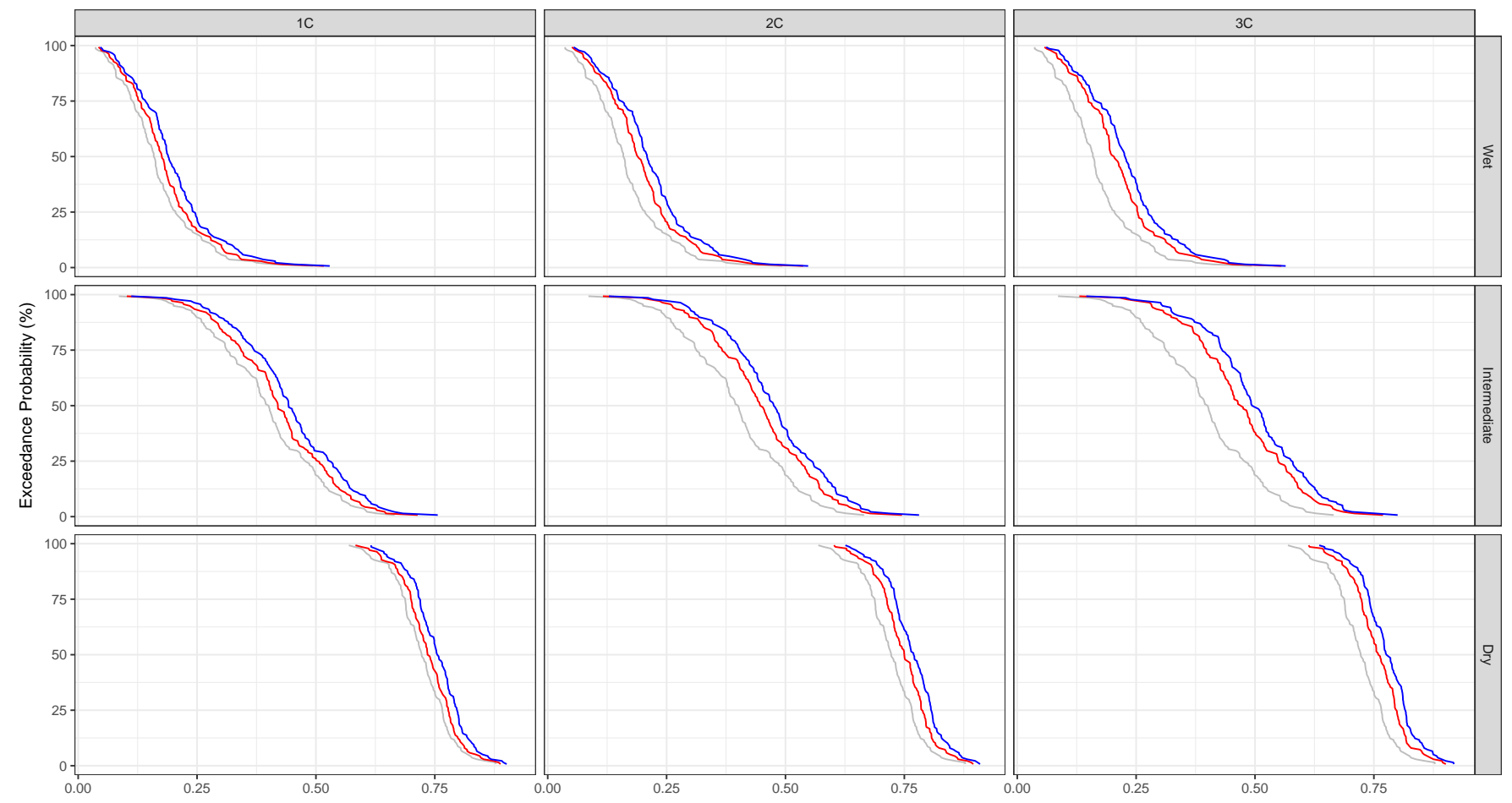

Scenario — Historical — Warming Only — Warming and Reduced Precipitation

Figure 6. Exceedance probability curves of climate change (CC) scenarios for each zone (row) and each warming condition (column). In all three zones, historical values are significantly different from CC scenarios $(\mathrm{p}<0.01)$ except for the $1 \mathrm{C}$ warming only scenario. In the dry zone, the warming only curves are significantly different from the warming with reduced precipitation curves under $1 \mathrm{C}$ and $2 \mathrm{C}(\mathrm{p}<0.1)$ and $3 \mathrm{C}(\mathrm{p}<0.05)$.

and reduced precipitation are observed at both of the intermediate stations and at only one of the seven dry zone stations (Table A1). At the seasonal level, higher SMDs and higher variability are calculated with greater impacts in periods linked to the northeast/inter-monsoon (Jan-Mar) across the country and to the southwest monsoon (May-Sep) in the intermediate zone (Figure 7). The lag in SMDs (Jan-Mar) observed from the reduced precipitation in Oct-Dec indicate the buffering impact of soil water holding capacities while the immediate impacts of reduced precipitation on SMDs in Apr-May indicate the enhancing impact of soils during drier climates (Salley et al., 2016). Although deficits are high for more than eight months in the dry zone historically, only the Jan and Oct months show changes under climate change. Even though SMDs will not increase under warming scenarios when already at a maximum value (e.g., in the dry zone in May-Sep), the higher atmospheric evaporative demand will require more water if moisture deficits are to be offset by irrigation. In the intermediate zone, eight consecutive months (Feb-Sep) show increases in deficits under climate change scenarios. These changes are critical in preparation for paddy cultivation in the intermediate zone, since crop yield is influenced by both magnitude and period length of water stress in the 
Hydrol. Earth Syst. Sci. Discuss., https://doi.org/10.5194/hess-2017-357

Manuscript under review for journal Hydrol. Earth Syst. Sci.

Discussion started: 11 July 2017

(c) Author(s) 2017. CC BY 4.0 License.

region (Perera et al., 2016). Increases in irrigation water needs would be particularly important during Jan-Mar and May-Jun, which coincide with critical growth stages of rice when soil moisture availability is a significant control on plant densities and crop yields, respectively (Mkhabela et al., 2005).

Sri Lanka is characterized by a radial drainage pattern with water flowing from the central hills outward (Figure 1). Irrigation

5 water supplied to the dry zone from reservoirs in the central hill country is of critical importance for agricultural production as more than $80 \%$ of the rice production in Sri Lanka comes from the intermediate and dry zones. Although temperature-driven changes increase deficits consistently across the country, differences in magnitudes of the shifts between the intermediate zone and dry zone (Figure 5) underscore the importance of considering spatial patterns in addition to temporal patterns for water management planning. While future irrigation water needs in the dry zone has received attention (e.g., De Silva et al. (2007)), future water needs of the intermediate zone, which are more locally-sourced, are less understood. The expansion plans of the Mahaweli irrigation system may buffer the dry zone from climate change impacts but not the intermediate zone of the country. Furthermore, increased competition for water will influence the amount of water available for irrigation (Perrone and Hornberger, 2016). Further evaluation of the transitional, intermediate region, which is also characterized by strong coupling of soil moisture and precipitation dynamics (Koster et al., 2004), is important for adaptation assessments.

The interrelationships among climate, soil moisture, and crop productivity are complex (Kang et al., 2009). Although different regions of the world will be impacted differently, expectations are that climate change may result in about a $20 \%$ increase in irrigation water requirements by 2080 over and above those needed to accommodate expansion of land under irrigation (Fischer et al., 2007), a level broadly consistent with estimates for paddy production (De Silva et al., 2007). Assuming no changes in precipitation, Davis et al. (2016) showed that closing yield gaps and increasing harvest frequencies will enable Sri

20 Lanka's rice production to keep pace with population growth. Our work indicates that water stress impacts from increasing temperature may greatly outweigh those from precipitation changes in endangering future self-sufficiency of rice on the island. Farmers' sensitivities to soil moisture can also strongly influence crop decisions (Du et al., 2017). Williams and Carrico (2017) identified that water-stressed farmers are significantly more likely to plant non-rice crops in their paddy lands than are water secure farmers. The implication is that increased water stress (as indicated by changes in SMD calculated in our climate change scenarios) may lead to a significant reduction of rice production. Water requirements planning (and therefore crop decisions) could be informed by soil moisture projections, which could be generated by adapting SMD calculations to use seasonal climate forecasts; the impact of seasonal forecasts on crop selections, which influences farmer income, has been demonstrated by Gunda et al. (2017). In this instance, SMAP data could be used to update the SMD model and seasonal forecasts periodically.

\section{Conclusions}

Soil plays a key role in terrestrial water dynamics by retaining precipitation on land. We identify that a combination of local climate and soil properties drive spatial patterns of soil moisture deficits in Sri Lanka, with soils buffering climate variability in the wet zone and enhancing drought patterns in the dry zone. Changes in temporal patterns are the most notable for the zone with intermediate climate (i.e., neither consistently wet nor consistently dry), which experienced the largest increases 
Hydrol. Earth Syst. Sci. Discuss., https://doi.org/10.5194/hess-2017-357

Manuscript under review for journal Hydrol. Earth Syst. Sci.

Discussion started: 11 July 2017

(c) Author(s) 2017. CC BY 4.0 License.

(c) (1)
Hydrology and

in seasonal median values and annual deficit probabilities both historically and under climate change scenarios. Our results indicate the exceedance probabilities of annual SMDs in tropical rice growing regions will exceed historical probabilities by up to $20 \%$ from temperature increases alone. The findings from this study have implications for decisions about infrastructural planning and seasonal crop water allocations. Because soil hydrologic regimes reflect inherent, local vulnerabilities that 5 could potentially exacerbate meteorological drought conditions (Zaitchik et al., 2006; Salley et al., 2016), water management decisions need to incorporate soil moisture dynamics in climate change adaptation assessments. Given increased competition, resource planners in various water use sectors will have to coordinate if deleterious impacts of competition for water are to be minimized. As downscaling methods improve, SMAP data could provide valuable insights for informing local practices.

Data availability. Soil moisture deficit calculations for the work reported here can be reproduced following the procedures described. The primary climate data were obtained from the Meteorological Department of Sri Lanka, which controls the distribution of the data. Missing data were infilled using methods described fully by Gunda et al. (2016). Calculated soil moisture values can be reproduced using the PDSI Matlab code available as supplementary information in Jacobi et al. (2013). 
Hydrol. Earth Syst. Sci. Discuss., https://doi.org/10.5194/hess-2017-357

Manuscript under review for journal Hydrol. Earth Syst. Sci.

Discussion started: 11 July 2017

(c) Author(s) 2017. CC BY 4.0 License.
Hydrology and Earth System Sciences

Discussions
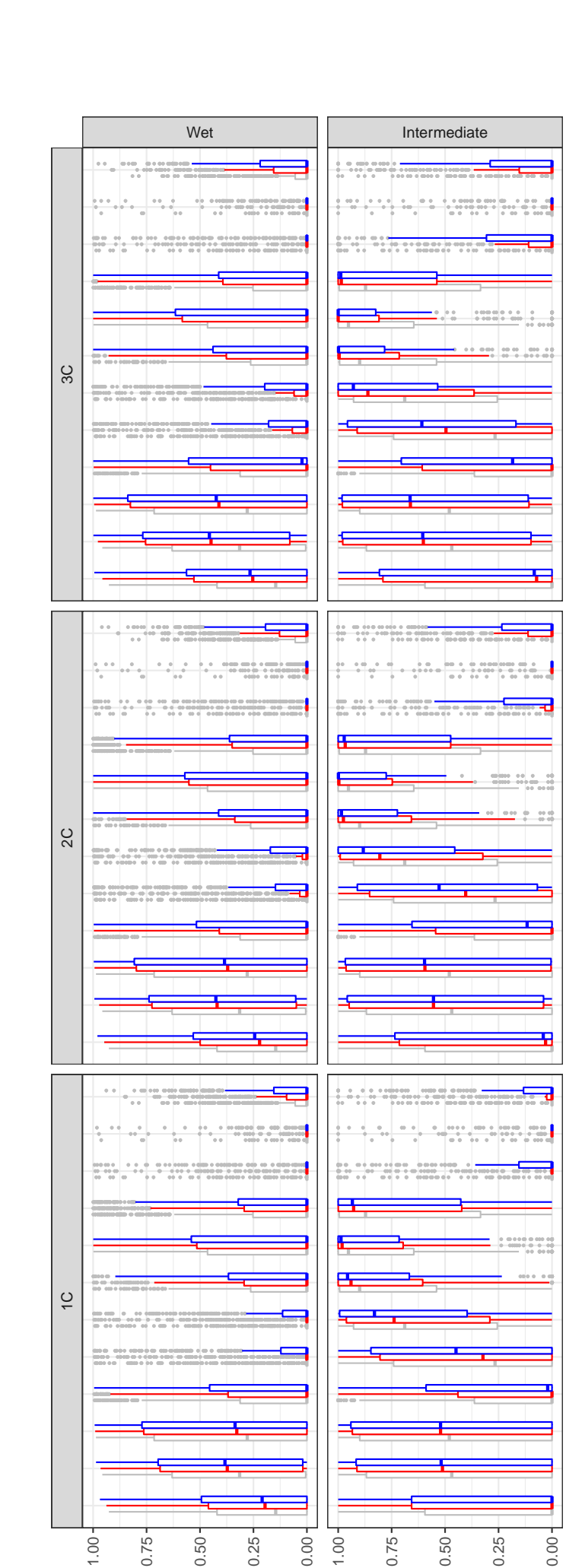

$$
\text { 量 }
$$

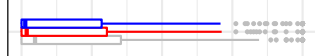

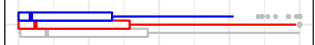
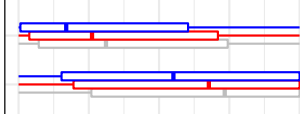

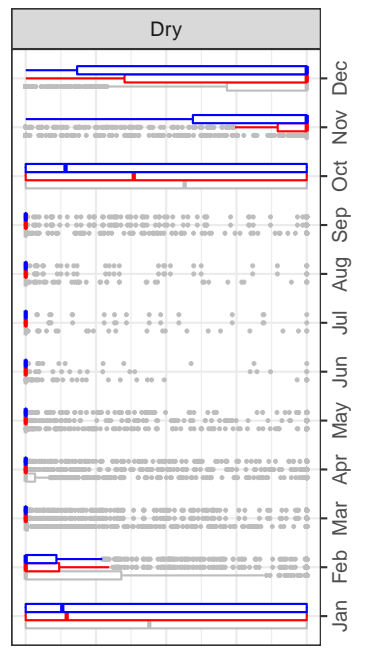


Hydrol. Earth Syst. Sci. Discuss., https://doi.org/10.5194/hess-2017-357

Manuscript under review for journal Hydrol. Earth Syst. Sci.

Discussion started: 11 July 2017

(C) Author(s) 2017. CC BY 4.0 License.
Hydrology and Earth System Sciences

Discussions (c) (1)

Table A1. Wilcoxon-Mann-Whitney test p-values of station-level differences between historical conditions and climate change scenario exceedance probability curves ( $\mathrm{p}$ values $<0.05$ are colored in red). No differences were observed at any of the stations between warming only and warming + reduced precipitation curves at $1 \mathrm{C}, 2 \mathrm{C}$, or $3 \mathrm{C}$.

\begin{tabular}{|c|c|c|c|c|c|c|c|}
\hline Zone & Station & $1 \mathrm{C}$ & 1C + Red. Precip. & 2C & 2C + Red. Precip. & 3C & 3C + Red. Precip. \\
\hline \multirow{5}{*}{ Wet } & Colombo & 0.75 & 0.02 & 0.03 & 0.00 & 0.00 & 0.00 \\
& Galle & 0.90 & 0.03 & 0.02 & 0.00 & 0.00 & 0.00 \\
& Nuwara Eliya & 1.00 & 1.00 & 1.00 & 1.00 & 1.00 & 1.00 \\
& Ratnapura & 1.00 & 1.00 & 0.63 & 0.12 & 0.07 & 0.01 \\
\hline \multirow{3}{*}{ Intermediate } & Badulla & 0.43 & 0.02 & 0.00 & 0.00 & 0.00 & 0.00 \\
& Kurunegala & 0.76 & 0.02 & 0.04 & 0.00 & 0.00 & 0.00 \\
\hline \multirow{5}{*}{ Dry } & Anuradhapura & 0.88 & 0.01 & 0.04 & 0.00 & 0.00 & 0.00 \\
& Batticaloa & 1.00 & 0.92 & 1.00 & 0.11 & 0.20 & 0.01 \\
& Hambantota & 1.00 & 0.01 & 0.14 & 0.00 & 0.01 & 0.00 \\
& Jaffna & 1.00 & 0.37 & 0.45 & 0.01 & 0.06 & 0.00 \\
& Mannar & 1.00 & 0.05 & 0.45 & 0.00 & 0.08 & 0.00 \\
& Puttalam & 1.00 & 0.02 & 0.15 & 0.00 & 0.01 & 0.00 \\
& Trincomalee & 1.00 & 0.29 & 0.48 & 0.01 & 0.08 & 0.00 \\
\hline
\end{tabular}


Hydrol. Earth Syst. Sci. Discuss., https://doi.org/10.5194/hess-2017-357

Manuscript under review for journal Hydrol. Earth Syst. Sci.

Discussion started: 11 July 2017

(c) Author(s) 2017. CC BY 4.0 License.

\section{(c) (i)}

\section{Hydrology and Earth System Sciences \\ Discussions}
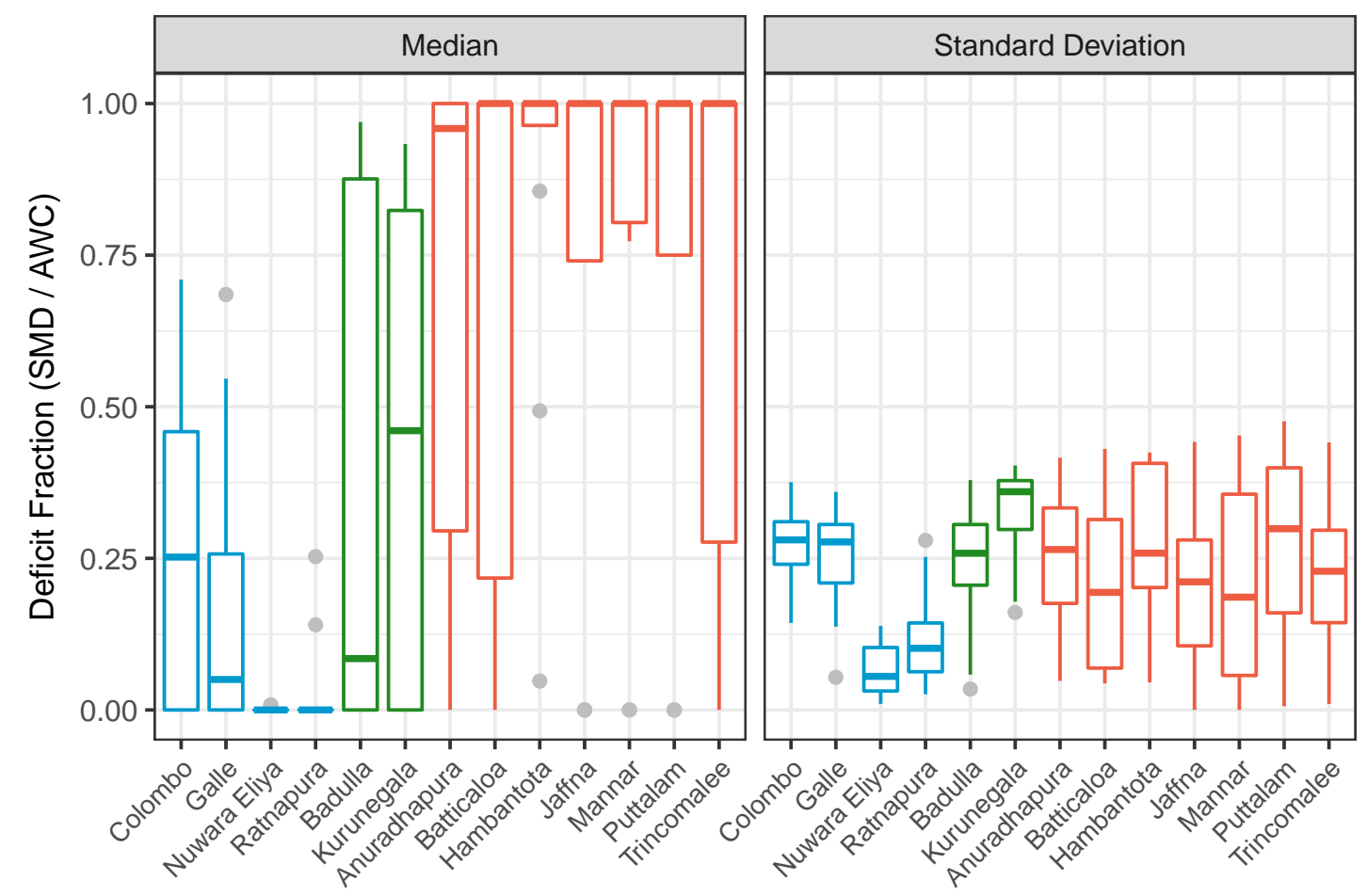

Zone

$\rightleftarrows$ Wet Intermediate

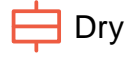

Figure A1. Median (left) and standard deviations (right) of monthly deficits. There is more intra-zonal variability among the wet zone stations than among stations in the other two zones. 
Hydrol. Earth Syst. Sci. Discuss., https://doi.org/10.5194/hess-2017-357

Manuscript under review for journal Hydrol. Earth Syst. Sci.

Discussion started: 11 July 2017

(c) Author(s) 2017. CC BY 4.0 License.

Hydrology and

Earth System

Sciences

Discussions

(c) (1)
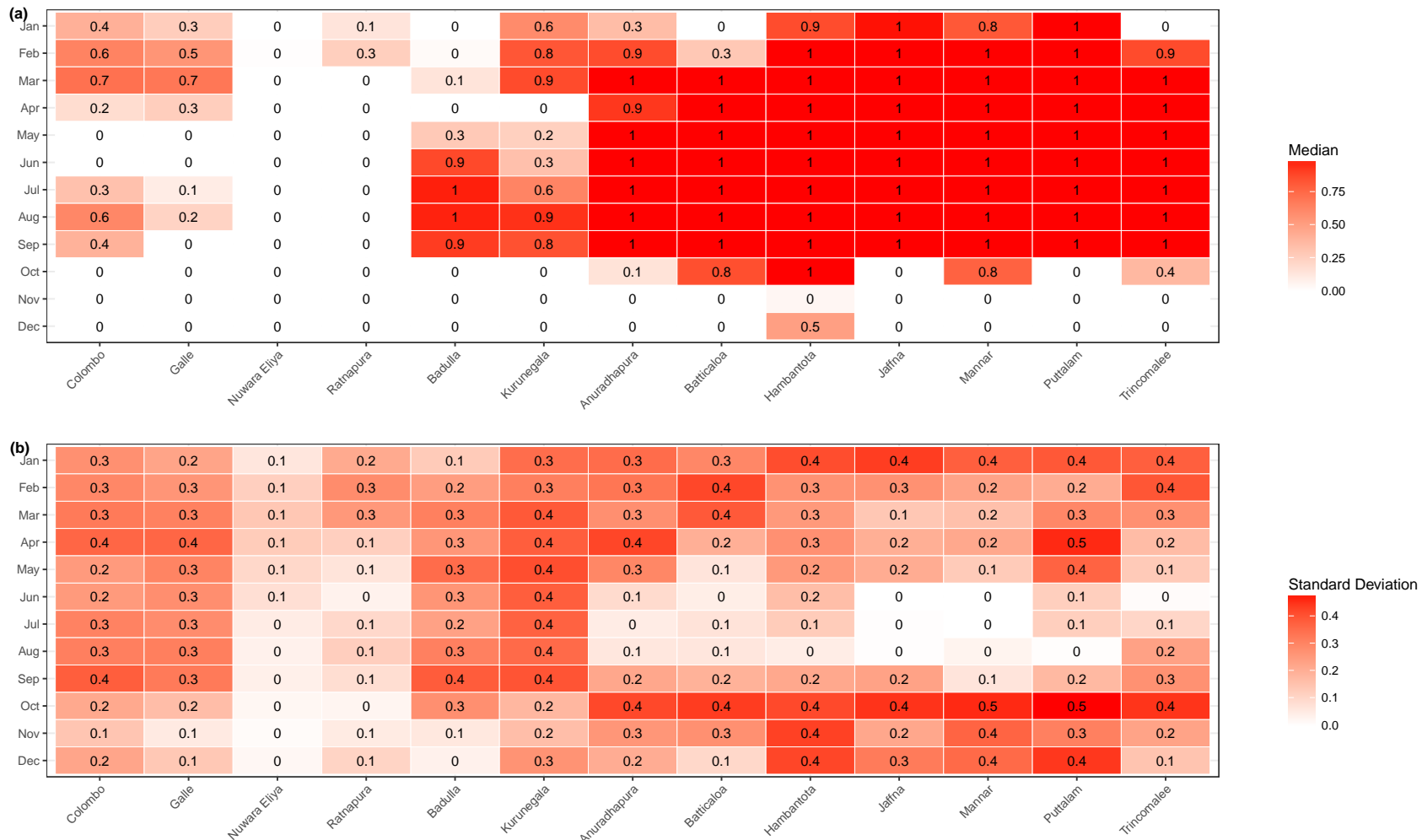

Figure A2. Heatmaps of (a) Median and (b) standard deviation of monthly soil moisture deficit fractions at each station. Nuwara Eliya and Ratnapura have consistently low deficits throughout the year while the dry zone stations are consistently dry Jun-Aug. 
Hydrol. Earth Syst. Sci. Discuss., https://doi.org/10.5194/hess-2017-357

Manuscript under review for journal Hydrol. Earth Syst. Sci.

Discussion started: 11 July 2017

(c) Author(s) 2017. CC BY 4.0 License.
Hydrology and Earth System Sciences Discussions
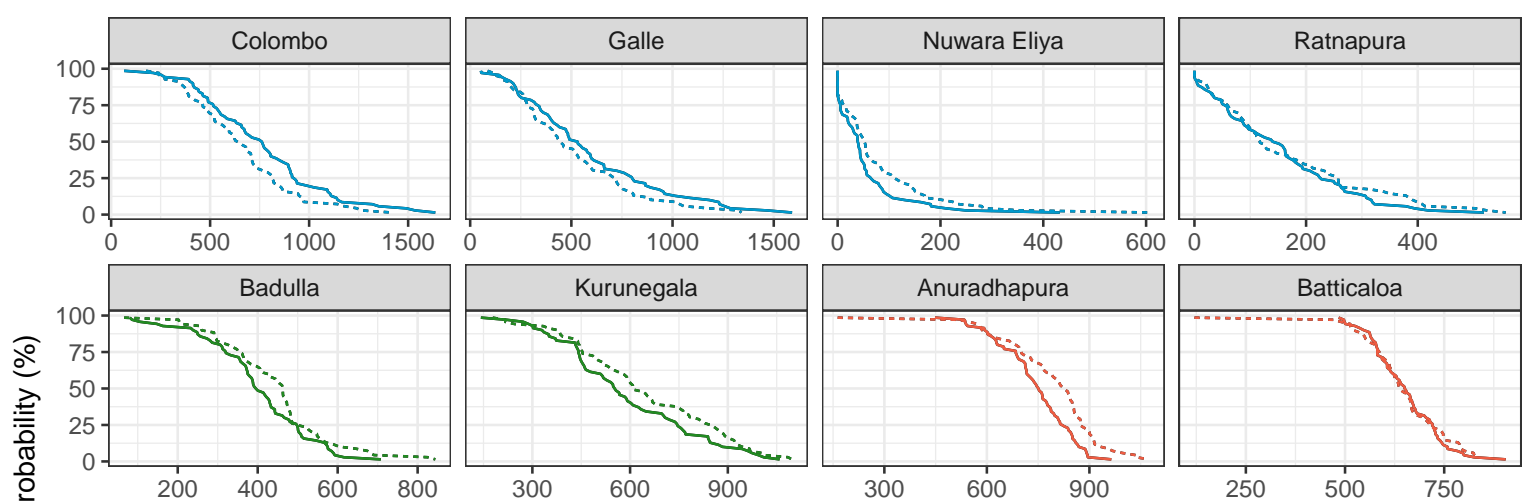

$$
300
$$
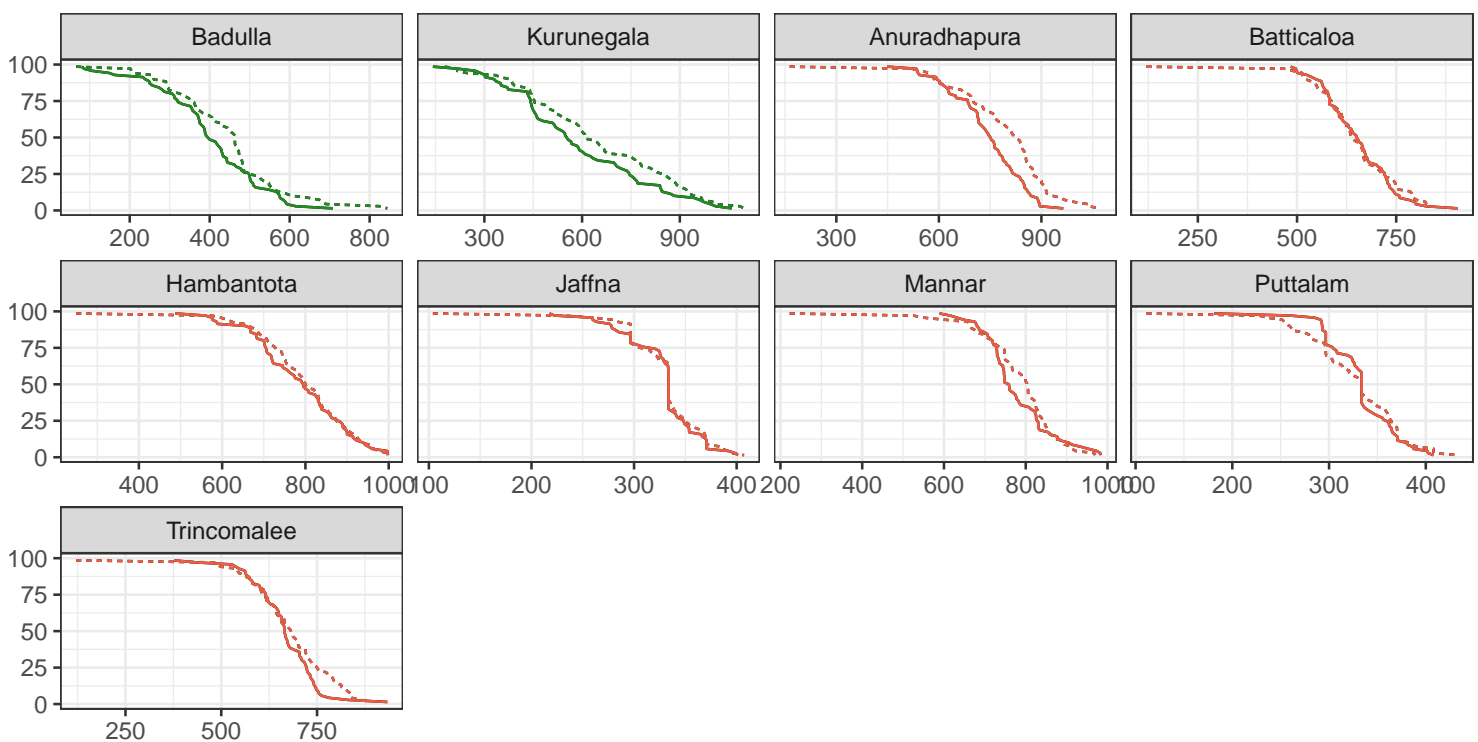

Period

- Until 1946

-... After 1946

Zone

- Wet

- Intermediate

- Dry

\section{Annual Cumulative Deficit (mm)}

Figure A3. Annual cumulative deficit comparison at each station until and after 1946. Exceedance probabilities for a given deficit are greater at Anuradhapura $(\mathrm{p}<0.01)$ and lower at Colombo $(\mathrm{p}<0.05)$ after 1946. 
Hydrol. Earth Syst. Sci. Discuss., https://doi.org/10.5194/hess-2017-357

Manuscript under review for journal Hydrol. Earth Syst. Sci.

Discussion started: 11 July 2017

(c) Author(s) 2017. CC BY 4.0 License.

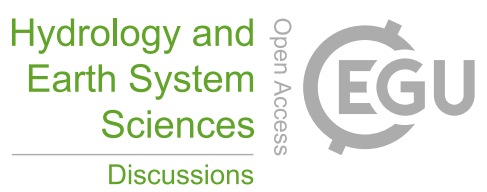

(c) (1)

Author contributions. TG conducted the statistical analyses and prepared the figures and tables. UPN conceived the project and performed soil moisture calculations. All authors participated in the interpretation of the results and in writing the manuscript

Competing interests. The authors declare that no competing interests are present.

Acknowledgements. This work was supported by the National Science Foundation (NSF) Grant No. EAR-1204685 and by NSF Graduate

5 Research Fellowship Program under Grant No. DGE-0909667. TG would like to thank the instructors (especially AJ Purdy) of the NASA remote sensing workshop at CUAHSI for the introduction and code to access the SMAP dataset. The University of Moratuwa, Sri Lanka is kindly acknowledged for granting sabbatical leave to UPN to conduct this study at Vanderbilt University, USA. 
Hydrol. Earth Syst. Sci. Discuss., https://doi.org/10.5194/hess-2017-357

Manuscript under review for journal Hydrol. Earth Syst. Sci.

Discussion started: 11 July 2017

(c) Author(s) 2017. CC BY 4.0 License.

\section{References}

Aydin, M., Vithanage, M., Mowjood, M., Jung, Y.-S., Yang, J. E., Ok, Y. S., Kim, S. C., and Dissanayake, C.: Estimation of evaporation and drainage losses from two bare soils in Sri Lanka, EURASIAN JOURNAL OF SOIL SCIENCE (EJSS), 1, 1-9, 2012.

Berg, A., Sheffield, J., and Milly, P. C.: Divergent surface and total soil moisture projections under global warming, Geophysical Research Letters, 44, 236-244, 2017.

Bolten, J. and Crow, W.: Improved prediction of quasi-global vegetation conditions using remotely-sensed surface soil moisture, Geophysical Research Letters, 39, 2012.

Botter, G., Peratoner, F., Porporato, A., Rodriguez-Iturbe, I., and Rinaldo, A.: Signatures of large-scale soil moisture dynamics on streamflow statistics across US climate regimes, Water resources research, 43, 2007.

10 Cohen, S., Strzepek, K. M., and Yates, D. N.: Climate change and water balance components, in: Water resources management in the face of climatic/hydrologic uncertainties, edited by Kaczmarek, Z., Strzepek, K., Somlyody, L., and Priazhinskaya, V., pp. 30-45, Springer Science and Business Media, 1996.

Conover, W. J. and Iman, R. L.: Rank transformations as a bridge between parametric and nonparametric statistics, The American Statistician, 35, 124-129, 1981.

15 Cooray, P. G.: An introduction to the geology of Ceylon, 2nd edition, National Museums of Ceylon Colombo, 1984.

Dai, A., Trenberth, K. E., and Qian, T.: A global dataset of Palmer Drought Severity Index for 1870-2002: relationship with soil moisture and effects of surface warming, Journal of Hydrometeorology, 5, 1117-1130, 2004.

Davis, K. F., Gephart, J. A., and Gunda, T.: Sustaining food self-sufficiency of a nation: The case of Sri Lankan rice production and related water and fertilizer demands, Ambio, 45, 302-312, 2016.

20 De Silva, C., Weatherhead, E., Knox, J. W., and Rodriguez-Diaz, J.: Predicting the impacts of climate change-A case study of paddy irrigation water requirements in Sri Lanka, Agricultural water management, 93, 19-29, 2007.

De Silva, C. S. and Rushton, K. R.: Groundwater recharge estimation using improved soil moisture balance methodology for a tropical climate with distinct dry seasons, Hydrological Sciences Journal, 52, 1051-1067, 2007.

De Silva, J. and Sonnadara, D.: Century scale climate change in the central highlands of Sri Lanka, Journal of Earth System Science, 125 , 75-84, 2016.

DOA: Integrated Plant Nutrition Systems (IPNS) Training Manual, Tech. rep., Department of Agriculture of Sri Lanka, https://www.doa.gov. lk/publications/books/ipns.pdf, 2017.

Du, E., Cai, X., Brozović, N., and Minsker, B.: Evaluating the impacts of farmers' behaviors on a hypothetical agricultural water market based on double auction, Water Resources Research, 53, 4053-4072, 2017.

30 Eitzinger, J., Štastná, M., Žalud, Z., and Dubrovskỳ, M.: A simulation study of the effect of soil water balance and water stress on winter wheat production under different climate change scenarios, Agricultural Water Management, 61, 195-217, 2003.

Fischer, G., Tubiello, F. N., Van Velthuizen, H., and Wiberg, D. A.: Climate change impacts on irrigation water requirements: effects of mitigation, 1990-2080, Technological Forecasting and Social Change, 74, 1083-1107, 2007.

Folberth, C., Skalskỳ, R., Moltchanova, E., Balkovič, J., Azevedo, L. B., Obersteiner, M., and Van Der Velde, M.: Uncertainty in soil data can outweigh climate impact signals in global crop yield simulations, Nature communications, 7, 2016.

Fournier, S., Reager, J., Lee, T., Vazquez-Cuervo, J., David, C., and Gierach, M.: SMAP observes flooding from land to sea: The Texas event of 2015, Geophysical Research Letters, 43, 2016. 
Hydrol. Earth Syst. Sci. Discuss., https://doi.org/10.5194/hess-2017-357

Manuscript under review for journal Hydrol. Earth Syst. Sci.

Discussion started: 11 July 2017

(c) Author(s) 2017. CC BY 4.0 License.

Fu, B., Wang, J., Chen, L., and Qiu, Y.: The effects of land use on soil moisture variation in the Danangou catchment of the Loess Plateau, China, Catena, 54, 197-213, 2003.

Garcia, E. and Tague, C.: Subsurface storage capacity influences climate-evapotranspiration interactions in three western United States catchments, Hydrology and Earth System Sciences, 19, 4845, 2015.

5 Gunda, T., Hornberger, G. M., and Gilligan, J. M.: Spatiotemporal patterns of agricultural drought in Sri Lanka: 1881-2010, International Journal of Climatology, 36, 563-575, 2016.

Gunda, T., Bazuin, J., Nay, J., and Yeung, K.: Impact of seasonal forecast use on agricultural income in a system with varying crop costs and returns: an empirically-grounded simulation, Environmental Research Letters, 12, 034 001, 2017.

Hawkes, C. V., Waring, B. G., Rocca, J. D., and Kivlin, S. N.: Historical climate controls soil respiration responses to current soil moisture, Proceedings of the National Academy of Sciences, p. 201620811, 2017.

Heim Jr, R. R.: A review of twentieth-century drought indices used in the United States, Bulletin of the American Meteorological Society, 83, 1149-1165, 2002.

Holzman, M. E., Rivas, R., and Piccolo, M.: Estimating soil moisture and the relationship with crop yield using surface temperature and vegetation index, International Journal of Applied Earth Observation and Geoinformation, 28, 181-192, 2014.

IPCC: Climate Change 2014: Synthesis Report. Summary for Policy Makers. Working Group I Contribution to IPCC Fifth Assessment Synthesis Report, Tech. rep., Intergovernmental Panel on Climate Change, https://www.ipcc.ch/publications_and_data/ar4/wg1/en/contents. html, 2014.

Jacobi, J., Perrone, D., Duncan, L. L., and Hornberger, G.: A tool for calculating the Palmer drought indices, Water Resources Research, 49, 6086-6089, 2013.

20 Kang, Y., Khan, S., and Ma, X.: Climate change impacts on crop yield, crop water productivity and food security-A review, Progress in Natural Science, 19, 1665-1674, 2009.

Karmakar, R., Das, I., Dutta, D., and Rakshit, A.: Potential effects of climate change on soil properties: A review, Science International, 4 , $51-73,2016$.

Keerthisena, R., Mapa, R., and Yapa, P.: Soil water dynamics in alley cropping systems in the dry zone of Sri Lanka, Tropical Agricultural Research, 13, 123-133, 2001.

Koster, R. D., Dirmeyer, P. A., Guo, Z., Bonan, G., Chan, E., Cox, P., Gordon, C., Kanae, S., Kowalczyk, E., Lawrence, D., et al.: Regions of strong coupling between soil moisture and precipitation, Science, 305, 1138-1140, 2004.

Li, G., Xie, S.-P., and Du, Y.: Monsoon-induced biases of climate models over the tropical Indian Ocean, Journal of Climate, 28, 3058-3072, 2015.

30 Manzoni, S., Schimel, J. P., and Porporato, A.: Responses of soil microbial communities to water stress: results from a meta-analysis, Ecology, 93, 930-938, 2012.

Mapa, R., Somasiri, S., and Dassanayake, A.: Soils of the dry zone of Sri Lanka. Special Publication No. 9. Soil Science Society of Sri Lanka., Suvodaya Vishwa Lecka publishers, 2010.

MASL: Seasonal summary reports for Yala 2015, Tech. rep., Mahaweli Authority of Sri Lanka, http://mahaweli.gov.lk/en/water.html, 2015.

Massari, C., Brocca, L., Moramarco, T., Tramblay, Y., and Lescot, J.-F. D.: Potential of soil moisture observations in flood modelling: estimating initial conditions and correcting rainfall, Advances in Water Resources, 74, 44-53, 2014.

McColl, K. A., Alemohammad, S. H., Akbar, R., Konings, A. G., Yueh, S., and Entekhabi, D.: The global distribution and dynamics of surface soil moisture, Nature Geoscience, 10, 100-104, 2017. 
Hydrol. Earth Syst. Sci. Discuss., https://doi.org/10.5194/hess-2017-357

Manuscript under review for journal Hydrol. Earth Syst. Sci.

Discussion started: 11 July 2017

(c) Author(s) 2017. CC BY 4.0 License.

Mikunthan, T. and De Silva, C.: Estimation of groundwater recharge in limestone aquifer using an improved soil moisture balance method: a case study in Jaffna district, Tropical Agricultural Research, 21, 2010.

Mkhabela, M. S., Mkhabela, M. S., and Mashinini, N. N.: Early maize yield forecasting in the four agro-ecological regions of Swaziland using NDVI data derived from NOAA's-AVHRR, Agricultural and Forest Meteorology, 129, 1-9, 2005.

5 Moorman, F. and Panabokke, C.: Soils of Ceylon, Trop. Agric, 117, 69, 1961.

Palmer, W. C.: Meteorological Drought, Tech. rep., US Department of Commerce, Research Paper No. 45, 1965.

Pender, J. L. and Kerr, J. M.: Determinants of farmers' indigenous soil and water conservation investments in semi-arid India, Agricultural Economics, 19, 113-125, 1998.

Peng, J., Loew, A., Merlin, O., and Verhoest, N. E.: A review of spatial downscaling of satellite remotely sensed soil moisture, Reviews of Geophysics, 2017.

Perera, A. C. S., Gunawardena, E. R. N., and Punyawardena, B. V. R.: Relationship between soil moisture deficit and productivity of paddy lands in a major irrigation system in Intermediate zone of Sri Lanka, Tropical Agricultural Research, 27, 295-304, 2016.

Perrone, D. and Hornberger, G.: Frontiers of the food-energy-water trilemma: Sri Lanka as a microcosm of tradeoffs, Environmental Research Letters, 11, 014005, 2016.

15 Rajapaksha, K., Mapa, R., and Sassanayake, A.: Effect of texture and organic matter on soil water retention parameters, Tropical Agricultural Research, 14, 224-232, 2002.

Salley, S. W., Sleezer, R. O., Bergstrom, R. M., Martin, P. H., and Kelly, E. F.: A long-term analysis of the historical dry boundary for the Great Plains of North America: Implications of climatic variability and climatic change on temporal and spatial patterns in soil moisture, Geoderma, 274, 104-113, 2016.

Seneviratne, S. I., Corti, T., Davin, E. L., Hirschi, M., Jaeger, E. B., Lehner, I., Orlowsky, B., and Teuling, A. J.: Investigating soil moistureclimate interactions in a changing climate: A review, Earth-Science Reviews, 99, 125-161, 2010.

Seo, S.-N. N., Mendelsohn, R., and Munasinghe, M.: Climate change and agriculture in Sri Lanka: a Ricardian valuation, Environment and Development Economics, 10, 581-596, 2005.

Shantha, W. and Jayasundara, J.: Study on changes of rainfall in the Mahaweli upper watershed in Sri Lanka due to climatic changes and develop a correction model for global warming, in: International Symposium on the Stabilisation of Greenhouse Gas Concentrations. Hadley Centre, Met Office, Exeter, UK, 2005.

Sun, Y., Huang, S., Ma, J., Li, J., Li, X., Wang, H., Chen, S., and Zang, W.: Preliminary Evaluation of the SMAP Radiometer Soil Moisture Product over China Using In Situ Data, Remote Sensing, 9, 292, 2017.

Szép, I. J., Mika, J., and Dunkel, Z.: Palmer drought severity index as soil moisture indicator: physical interpretation, statistical behaviour and relation to global climate, Physics and Chemistry of the Earth, Parts A/B/C, 30, 231-243, 2005.

Várallyay, G. et al.: The impact of climate change on soils and on their water management, Agron Res, 8, 385-396, 2010.

Whan, K., Zscheischler, J., Orth, R., Shongwe, M., Rahimi, M., Asare, E. O., and Seneviratne, S. I.: Impact of soil moisture on extreme maximum temperatures in Europe, Weather and Climate Extremes, 9, 57-67, 2015.

Williams, N. E. and Carrico, A.: Examining adaptations to water stress among farming households in Sri Lanka's dry zone, Ambio, pp. 1-11, 2017.

Zaitchik, B. F., Macalady, A. K., Bonneau, L. R., and Smith, R. B.: Europe's 2003 heat wave: A satellite view of impacts and land-atmosphere feedbacks, International Journal of Climatology, 26, 743-769, 2006. 
Hydrol. Earth Syst. Sci. Discuss., https://doi.org/10.5194/hess-2017-357

Manuscript under review for journal Hydrol. Earth Syst. Sci.

Discussion started: 11 July 2017

(c) Author(s) 2017. CC BY 4.0 License.

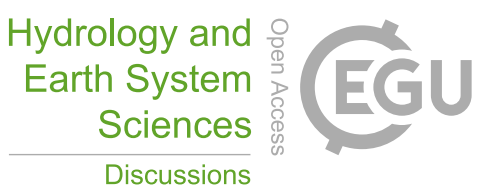

(c) (1)

Zubair, L.: El Niño-southern oscillation influences on the Mahaweli streamflow in Sri Lanka, International Journal of Climatology, 23, 91-102, 2003.

Zubair, L., Ralapanawe, V., Tennakoon, U., Yahiya, Z., and Perera, R.: Natural disaster risks in Sri Lanka: Mapping hazards and risk hotspots, in: Natural disaster hotspots case studies. Disaster Risk Management Series No. 6, pp. 109-136, World Bank, 2005.

5 Zubair, L., Nissanka, S. P., Weerakoon, W. M. W., Herath, D. I., Karunaratne, A. S., Prabodha, A. S. M., Agalawatte, M. B., Herath, R. M., Zeenas Yahiya, S., Punyawardhene, B. V. R., Vishwanathan, J., Delpitiya, P., Erandika, A., Wijekoon, N., Gunaratna, J., Chandrasekara, S. S. K., Wickramagamage, P., Weerasinghe, K. D. N., Navaratne, C. M., Perera, R. S., Gunesekara, A. I., Pradeep Kumara, G. M., Wallach, D., Valdivia, R. O., and McDermid, S.: Climate Change Impacts on Rice Farming Systems in Northwestern Sri Lanka, in: ICP Series on Climate Change Impacts, Adaptation, and Mitigation: Volume 3 Handbook of Climate Change and Agroecosystems, pp. 315-352, World

Scientific, 2015. 